Katharina Pewny

\title{
Tracing the Other in the Theatre of
} the Precarious (Lola Arias, Elfriede Jelinek, Meg Stuart, Wajdi Mouawad, Christoph Marthaler)

\begin{abstract}
In Precarious Life. The Powers of Mourning and Violence, Judith Butler poses the question if adequate representation of human vulnerability is possible against the background of media representations of violence and suffering during the Iraq war. She takes Emmanuel Lévinas's concept of the "precarious other" as her starting point. In addition to Lévinas's sense of the face, Butler also considers the sense of hearing or the acoustic mediation of vulnerability, and she asks for media that could mediate the vulnerability that is (according Lévinas, and to herself) at the core of humanity: "One would need to hear the face as it speaks in something other than language to know the precariousness of life that is at stake. But what media will let us know and feel that frailty, know and feel at the limits of representation as it is currently cultivated and maintained?" (151). I propose that the portrayal of the suffering and precariousness of the other are created and mediated in some contemporary Performing Arts. Further, I propose the precariousness of the other appears in a profound manner when they are represented, not in a primarily visual manner, but by appealing to and involving the spectators' other senses, such as the sense of smell, hearing, body perception. From the enormous body of contemporary theatre works that employ the spectator's senses, I choose pieces by Elfriede Jelinek Meg Stuart, Wajdi Mouawad, and Christoph Marthaler. Their performances are multi-sensory encounters with the precariousness of the other, and, as "postdramatic" performances, they are all situated at the edge of drama, in music theatre. In the following, I first introduce Lévinas's ethics, a key point of departure for both Butler's and my own work. Secondly, I elaborate on how I translate it in performances of the precarious. Thirdly, I discuss three examples from the international context of theater performances that engage human vulnerability especially strongly.
\end{abstract}

Keywords: theatre, the other, precariousness, postdramatic

DOI 10.1515/arcadia-2014-0024

Katharina Pewny: Ghent University, St. Pietersnieuwstraat 41, 9000 Ghent, Belgium, E-Mail: Katharina.Pewny@UGent.be 


\section{Lévinas's ethics and its significance for performance studies}

Emmanuel Lévinas was born in Kaunas (Lithuania) in 1906. In 1923, he moved to France where he lived until his death in 1995. In Lévinas's ethics, written in the historical context of the Holocaust, the encounter of the self with the other is central, for it constitutes the subject status of the self through its responsibility for the (vulnerable or previously violated) other. Both aspects are inextricably bound to one another because, for the philosopher, the self becomes human by acknowledging the other (Lévinas, Ethics and Infinity 78). The humanity of the self resides in the acknowledgement of the mortality and vulnerability of the other and in making the Other's concerns one's own. The exposure of the other is an invocation, command or supplication for the self to take responsibility (Lévinas, Ethics and Infinity 163). The command to take responsibility for the respective other stays with one for an entire lifetime. This implies that it is impossible to conceive of an existence without the other and without the responsibility for the other. Taking responsibility constitutes one's humanity, however, the existence of the other cannot exclusively be conceived of in terms of humanity. For Emmanuel Lévinas, the other, who is considered "precarious," oscillates between a worldly concretization as fellow man and a transcendental, godlike abstraction (Lévinas, Basic Philosophical Writings 167). In her 2004 book on human vulnerability and its implications, Judith Butler takes up this notion of the "precarious" and pleads for a societal recognition of mourning for the violation of human beings and their rights (128-153). By doing so, she expresses a (new) definition of the human: precisely the human vulnerability that Lévinas calls "precarious": "I think it is an ontological claim and the claim is that human life is precarious (Butler "Precariousness and Violence" 136). Butler aims at a collective recognition of suffering (in the present political condition of the VS), and in this context she asks the above cited question for the different media's implications of this. Furthermore, Butler's publication brings Lévinas model of the constitution of the subject back into the academic awareness and, by reflecting on media representation, opens up Lévinas ethics for Theatre and Performance Studies. Whereas the "precarious" depicts (for Butler) two phenomena, namely the human condition (of vulnerability) per se and discriminatory speech ("Precariousness and Violence" 136f), I use it in the first sense, which is also the sense of Lévinas: a fundamentally human vulnerability that is attacked by crimes against humanity and many times re-staged by theatre makers.

I thus propose translating the Lévinasian ethics of encounter into performance analysis and contend that the ethics of theatrical performances lie in how 
the (according to Lévinas and Butler: precarious) other faces the spectators. In other words, theatrical performances constitute an encounter with the other when possibilities are opened up for the spectators to respond to the vulnerability of the other. As in Lévinas, where each subject is constituted through the invocation of the other, the audience only becomes an audience in the face of the performance. The spectators regard the other nolens volens while, and in the moment of, taking up their positions (as spectators), which, in turn, can only be constituted through the encounter with the vulnerable other. Regardless if a spectator is obviously engaging with a performance or appears to be passively sitting there, each position the spectator assumes constitutes a response to the command of the other - insofar as it has been assigned to them. The possible responses, however, must remain proposals, for they are situated on an ethical (rather than moral) plane, and can therefore neither be prescribed nor completely reconstructed. This does not necessarily lead to a representation of the other, as Lévinas does not necessarily seek to examine an encounter between two people. On the contrary, in Lévinas it is often unclear if the other is divine or human (Ridout 54-61). Instead, Lévinas's figure of the Other points to how representations of the same are always flawed (Butler Precarious Life 133). This flaw corresponds to postdramatic theater aesthetics, which rarely seek to create the illusion of theatrical representation.

One example for contemporary “postdramatic” performances is Lola Arias's performance of My Life After (2009), in which memories of resistance fighters and people who belonged to the Argentine military dictatorship during the 1970s are performed by her own children, who are professional performers (Arias). Historical persons are also present in other moments of the performances, for example through photographs, their personal clothing, anecdotes, or letters. The performers convey their own encounters with the other (their parents, some of whom are deceased), an irretrievable past that precedes them, without embodying their parents theatrically. Arias' piece invites the spectators to construct a narrative for their own around the dramatic figure's/performers personal histories, and especially the simultaneity of victims and perpetrators (of the Argentinian military regime) perspectives bears strong resemblances with performances reflecting on the cruel history of the Holocaust. The step away from representation through (conventional) acting is used by the director to stage a period of crime against humanity that is often to be found in performances from the past thirty years. But, what is "postdramatic", and why is Arias piece a good example for this? In 1999, German theatre scholar Hans-Thies Lehmann introduced the "postdramatic" as new term to depict performance pieces produced since the nineteen-seventies that do not take the dramatic text as primary point of reference. Although the "postdramatic" can appear in an endless variety of aesthetics on stage, some of 
its important elements are muzicalisation, an emphasis on bodily presence, the simultaneity of theatrical signs (instead of the dominance of a pre-written dramatic text), and an inclusion of Fine Arts and Performance Arts aesthetics into the (former) theatre of the spoken word that has since then irrevocably changed. In his most recent reflections on the postdramatic, Lehmann points out that though it is (still) neither desirable nor possible to define the "postdramatic," there is a certain mode of self-reflexivity attributed to it:

"Postdramatisches Theater ist Theater mit Bewußtsein davon, eine Kunst sui generis zu sein - als Installation, als szenische Narration, als Stadtspaziergang, als Performance, als Tanz, als Tanztheater, als quasi-politische, aber ästhetisch motivierte Aktion, als Vorgang im Kunstraum oder im öffentlichen Raum, kurz: mit literarischer und poetischer Dimension oder ohne sie." ("postdramatische Chance” 2)

Because postdramatic theatre forms very often reflect on theatrical aesthetics and thus also on the role of the spectator, they are sometimes employed to stage difficult political histories such as crimes against humanity in the frame of the Holocaust, or military dictatorships. The work of Elfriede Jelinek is a well know example for this. German director Jossi Wieler also doesn't stage any depictions of the mass murder of around three hundred Jewish people by the Nazis as the war was drawing to an end in his staging of Elfriede Jelinek's Rechnitz (Der Würgeengel) (2008). What is presented on stage at the Munich Kammerspiele is Jelinek's messenger monologue, which is about the fact that the messenger had not seen what happened either, and is therefore unable to report anything. Traces of the crime, and thus traces of the other, are present in the messenger's refusal to fulfill his duty. In the above-mentioned performances, the audience comes faceto-face with the trace of the other, which, in both cases, is based on historical events and on a traumatic history. Although neither of the performances explicitly calls upon the spectators to act, their fragmentary character, alongside unmistakable references to contemporary history (the military dictatorship in Argentina, Nazism in Germany and Austria), suggests that they search for historical contexts, and thereby create narratives.

These and many other performances, which depict the vulnerability of human existence, constitute a crucial part of what I call "theater of the precarious" in my book with the same German title. In the course of this larger study on contemporary performances I research aesthetic strategies of theatre makers who stage an encounter with the vulnerable other. Precariousness in these performances denotes a fundamental vulnerability, and thus, instability, of the human as such, that Butler also points out. Theatre makers perform instability in two senses: in the sense of the vulnerability of the human on an ontological level, and in the sense of economic instability. The corpus of such a research is certainly 
international and huge, both in theatre history and in the present. I include in my study theatre works that circulated within the big theatre festivals, and institutions, from the year 2000 to 2010, in Germany and in Austria. The performances analyzed in this article form crucial part of that research, and they were chosen because the aesthetic strategies developed by the artists are representative and truly interesting. The examples chosen also activate the dialectics of memory and forgetting that is inherent in theatre dealing with (histories of) war and crimes against humanity (Schneider). Whereas theatre always works on and with the spectators senses, the works chosen here create encounters with the precarious other because they stage crimes against humanity (and, in the case of Meg Stuart, a catastrophe caused by nature) by means of a postdramatic aesthetics. This accounts for the fundamental change the theatre of the spoken word has undergone in the past decade, specifically in Germany and in Austria, where drama is still more present than, for example, in the Netherlands or in Flanders. Elsewhere, I discuss other performances from the theater of the precarious, which deal with economic developments related to a growing social inequality and, with it, the increasing insecurity of socially disadvantaged groups (Pewny "Performing the Precarious"). In the following, I focus on three further contemporary theater performances that stage human vulnerability in the face of forces of nature and human violence.

\section{Modes of enacting the Theater of the Precarious}

a) Meg Stuart Blessed (2007), Wajdi Mouawad Verbrennungen (Scorched) (2007)

The spectators of Meg Stuart's performance witness a gradual increase of vulnerability, or rather, of being exposed to the forces of nature. She developed the choreography Blessed (2007) three years after the tsunami of 2004, as (masses of) water appeared especially threatening.

The production by the New York choreographer, who founded the dance company Damaged Goods in Brussels in 1994 and has since received numerous awards, was awarded the French Prize of Criticism in 2008. In Blessed, the Portuguese choreographer Francisco Camacho dances in incessant rain. On the nearly empty black box stage, designed by Doris Dzierk, there are a large swan, a palm tree and a hut - all made of cardboard. Both the childish appearance of the cardboard accessories on the black, empty stage, and the extremely slow movements of the dancers convey a bleak, surreal atmosphere. After the incessant rains set in, the palm tree, swan and hut start to cave in and disintegrate into 
pieces that Camacho then wraps around his body. As the (dancer's) body is exposed to increasingly more rain, the surroundings merge with his skin, separating him from the outside world, from the uncontrollable powers (of nature). The dancer's body radius continually diminishes as he collapses more and more inward and recedes into himself. What is performed is an ongoing inscription, which occurs through the effacement of what is on stage. The props disintegrate slowly and quietly, the pitter-patter of the rain appears calming, and the air is filled more and more with humidity and the smell of rain. An aesthetic of quasi traumatic inscription has multi-sensory effects on the spectators, especially on the sense of hearing and smell. The humidity in the air sticks to the audience's skin, their noses become filled with the slightly musty smell that so many theaters have, which grows more intense through the moisture. Blessed functions through trauma in the sense that from the outset, the dismal, post-catastrophic stage setup and the dancer's slow movements point indicate that something undepictable may have preceded the scene. The performance shows a further increasing disintegration, a continuation of something that remains unknown to the spectators. In this way, the performance's aesthetic resembles a traumatic event, which Caruth, referring to Siegmund Freud's understanding of hysteria and then, trauma, describes as follows: "Trauma, that is, does not simply serve as record of the past but precisely registers the force of an experience that is not yet fully owned" (151). According to this, trauma and thus also posttraumatic theater are characterized by a duality, namely the simultaneity of presence and absence. In her theory of trauma, Caruth describes the difficulty of integrating trauma into the recollection, while simultaneously over-affirming the memory, as "it [memory] understands too much" (154). If attempted, "this often leads to melodrama or kitsch" (Siegmund 391). It is precisely the multiplicity of theatrical aesthetics within postdramatic theatre wherein non-representational aesthetics are developed. This includes a certain renunciation of the pre-written dramatic text, as well as a critical questioning of the prevalence of the visual (in mass media, but also in the Performing Arts).

In Blessed, a steadily increasing discomfort clings to the spectators' senses, as the sound of falling raindrops reaches their ears and the humidity touches their skin. In this way, the sensory experience of a destructive process through the forces of nature is staged without it being preceded by a documented event. By primarily working with sensory perception, rather than with a narration, the performance is able to escape the trap of theatrical representation: there is no transformation toward a narrative, the (spectators') memory that "understands too much" cannot be created. The "force of an experience," however, has left an imprint that is stored in the spectators' body memory, in the form of humidity and body moisture. In the first two examples mentioned here, the trace of the other, 
which engages the spectator's capacity to transform disparate information into a narration is, above all, inscribed into their bodies and thus into their body memory. In contrast to mass media that primarily employ visual signs to indicate suffering (see Butler above), Stuarts piece is a paradigmatic example for theatre's ability to engage smell and humidity in order to "flood" the spectator's senses.

Not only dance, but also the theatrical staging of dramatic texts can develop interesting posttraumatic aesthetics and ethics of encounters with the other. In 2007, Wajdi Mouawad's piece Verbrennungen, directed by Stefan Bachmann, premièred at the Akademietheater in Vienna. It draws on the tragic Oedipus motif and, just as Sophocles' tragic trilogy of the same name, the performance focuses on the progressive dialectic of a violence that leads to further violence. The story is based on the biography of the Lebanese resistance fighter Suha Bechara, who also saw the performances. Following an assassination attempt on the head of the South Lebanese army, Bechara was taken into custody at Khiam prison where she would sing when she heard the screams of those being tortured. In the play and in real life she is called the "woman who sings" (Bechara 19). In Verbrennungen, Mouawad describes Bechara's daughter and son's search for their unknown father and brother, a duty placed upon them in a letter from their deceased mother. Step by step, the mother's life story unfolds, first as a young woman and later as a Lebanese guerrillera. The siblings set off on a journey to Lebanon, to the past. Each place they visit, they learn more about their mother from a meddah, an Arabic storyteller. The various stories about their mother gradually lead them back into a past where a lot still remains to be explained. Eventually, the father and the brother prove to be the same person - the mother's jailor and rapist who appears in the international media as a clownish soldier. The critical reflection on visual representations of killing at the end of the performance mirrors Butler.

Although it is never stated explicitly, the spectators are supposed to believe that the clown/solider is the twins' father and brother, because the dramaturgical tension directly points to this conclusion. Through the silence, the trauma of incestuous rape attains a clear presence. What lies at the core of the trauma - and of the attempted assassination - remains outside the realm of scenic presentation and representation (Siegmund). The tension between the ineffable and the allusion to something terrible is performed on an acoustic level, as the song of the imprisoned Nawal is heard on stage, even after Nawal has already died in the story, and the siblings are confronted with the meddah's silence concerning their father's identity. The combination of silence and song acoustically conveys the denial of representation and the return of what has been experienced, which are both intrinsic to trauma, in the sense of "an experience not yet fully owned" (see Caruth above): the imprisoned woman's song outlives her(self). The precarious - 
in the sense of a traumatic injury that has already taken place - is inherent in the song, an injury that the children carry in themselves, more or less as their mother's legacy, due to the fact that they were born out of rape. The trace of the other, in this case, the theatrical figure Nawal, is inscribed in the acoustics. In Butler's sense, her precariousness is not visually portrayed on stage, but precedes the theatrical event, completely in the sense of Lévinas. The spectators, like the theatrical figures of the children, become witnesses who partake in the journey of uncovering the violent incest, without ever getting to the bottom of it. Their witnessing has the potential to transform the absent protagonist's silence into stories, when they speak of or write about their evening at the theater.

The third performance that I shall discuss in detail can also be considered a part of the (posttraumatic) theater of the precarious. Christoph Marthaler's staging of Protect Yourself from the Future (2005) brings together three characteristics already discussed above via Stuart and Mouawad/Bachmann: affecting the bodies of the spectators, the emphasis on an acoustic level, and the possibility of creating a narrative via the performance. These charactaristics are representative for other performances of the precarious (Pewny 133-141). Of course they are important in other so called "postdramatic" performances as well, but not all of them stage human vulnerability.

b) Christoph Marthaler (Schutz vor der Zukunft (Protect yourself from the Future) 2005-2010)

Swiss director Christoph Marthaler has been known since the 1980s for his theater events that contain musical elements (Roesner). From 2000-2005 he was artistic director of the Zurich Schauspielhaus, where he was asked to leave prematurely, supposedly due to budget cuts (Barnett 186). Many of his numerous productions were done in collaboration with dramaturge Stefanie Carp and stage designer Anna Viebrock. Marthaler's productions often have a dream-like atmosphere to them, created by Viebrock's distinct spatial concepts as well as the performers' slow movements, the music and song.

Marthaler's production Schutz vor der Zukunft performs injuries from an insecure existence on several levels. In terms of content, this refers to humanity as a so-called human resource within globalized economies and to the historical legacy of the Holocaust. Schutz vor der Zukunft interweaves the presence of past crimes against humanity - and thus against the insecure existence - with the present and future of post-Fordist working societies, without viewing them as one and the same. The precarious, in terms of the physical vulnerability and the uncertainty of perception, is performed through the transmission of physical pain from the stage to the spectators, and through the acoustic staging of the violent death. In the following, I introduce the production and then elaborate on these three mentioned levels. 


\section{a) The performance}

Christoph Marthaler's production of Schutz vor der Zukunft premièred at the Wiener Festwochen in May 2005, and was awarded the Austrian Nestroy Prize for Best Director in 2005. The following year, the production was invited to perform at the Berlin Theatertreffen and was also shown in Paris, Moscow, Chur, and Ghent. In 2010, the performance was shown at Festival d'Avignon. Although Schutz vor der Zukunft is well-known among international theater audiences, it remains underrepresented as a topic of analysis in scholarly work. If at all, it has only been briefly mentioned (Carlson 136; Barnett 185-205). In the following, I will be referring to the Viennese production, a site-specific performance shown at the Jugendstiltheater, on the grounds of the former psychiatric hospital Am Spiegelgrund, during the Wiener Festwochen in 2004 and 2005. Between 1940 and 1945, the areal Am Spigelgrund, today Baumgartner Höhe, included buildings that housed a "special ward for children" where at least seven hundred and eighty-nine children and adolescents were murdered under the Nazi euthanasia program. Currently, the Baumgartner Höhe Center for Social Medicine, which is the psychiatric ward of the Otto Wagner Hospital, the Otto Wagner Church of St. Leopold, and the Jugendstiltheater are all located on the institution's grounds. In remembrance of those who were murdered, seven hundred and seventy-two stellae have been put up on the lawn outside the theater, and are lit up at night.

Schutz vor der Zukunft opens with a scene that constantly switches between speech, song and music. The production encompasses all of the elements associated with Marthaler's aesthetics, that is to say the strong presence of musical elements, slow movements and humor, melancholy and the absurd. The performance opens with a scene that is nearly motionlessness. The audience in the Jugendstiltheater is seated at five long dining tables in a feudal-like space. Each individual person is isolated on their seat and set apart at an equal distance from the collective view. Simultaneously, eleven performers are sitting at a round table playing music: Rosemary Hardy, Markus Hinterhäuser, Ueli Jäggi, Jürg Kienberger, Katja Kolm, Bernhard Landau, Josef Ostendorf, Nicolas Rosat, Clemens Sienknecht, Bettina Stucky, and Jeroen Willems. After a few minutes, smaller, sporadic scenes start taking place around the dining tables. A clown makes macabre jokes, a woman sticks her head into a trombone. Then a performer steps up to a lectern, which is placed in front of a closed red curtain. He announces the "opening of the center," the "start of the summer season" and the "sale of individual products." The speakers alternate in rapid succession and become less and less articulate as their stuttering increases. Singular phrases, such as "donations for the tsunami disaster," "costs for the mental hospital," "day of entry," "day of murder," "care costs" stand out among all the babble. In the speeches and songs 
that follow, coherent excerpts from letters written by imprisoned children and their parents follow sentence fragments about human utility for the working world. We hear among others:

Grandma is already sixty-five and wants a new heart now... she wants fitness therapy ... We don't want to have to watch Grandma deteriorate every day, especially not at work ... We don't want to invest in unproductive progress either... learn to die at an appropriate age ... after all, they still want to look good when they are put under the earth!

The next bit of text seems to have been taken from a radio program:

The parents hope that their children have a good time on their field trip to Hartheim tomorrow ... and then, another mother who wants to make her little one's wish come true ... she wishes her son Hermann a happy fifth birthday ... she hopes he hasn't had to change rooms again and that this reaches him ... he supposedly annoyed the nurses so much that he had to sleep outside on the balcony as punishment ... he should be a good boy... then he'll be allowed visitors again.

In the beginning, the constant switching between narrative planes is confusing, although the location and the playbill both suggest that these are excerpts from letters written by parents, which are being read out loud to the children imprisoned in the hospital. At the end of the scene at the lectern, the representational function of the actors is introduced. Up until this point, the actors were unidentifiable as figures, here they begin to represent the "little ones," the imprisoned children, who "thought up something for their farewell" (author's emphasis) and set up an "orchestra." The instruments the actors play here, or stick their heads into, are the same ones the members of the orchestra play as they say good-bye. This is the first time the violent death, which the entire venue reeks of, explicitly comes into play. This clarification directs the audience's attention toward the site of the performance and to the specific historical events. The composition of the text links the Nazi paradigm of utility, which reduces children and youth to physical material for medical research, to a working world that only acknowledges people as a productive force (as a human resource). The clarification of the theatrical signs goes hand in hand with textually reducing humanity to human resources.

Hence, the violent intervention in the precarious vulnerability of the other is the non-recognition of its existence outside economic rationalization. Such a perspective assumes that humans are reduced to the materiality of the body or to what Italian philosopher Giorgio Agamben calls homo sacer (16-19). Viewing human beings as profitable material is a historically specific phenomenon found, for example, in Nazi medical research. In Schutz vor der Zukunft, Christoph Marthaler stages both the specific horror of euthanasia and an uncertain dis- 
comfort directed at the spectator's own potential future. Within this peace, there is the trace of what cannot fully be represented, or mimetically transferred to the audience because this is simply not possible. The precarious, in the sense of lacking security also the insecurity of the "correct" way to stage, or research, crimes against humanity - is nevertheless apparent through the bodily intactness of the imprisoned youth and through the human capacity, as workers, to produce a commodity that can be offered on the labor market as a means of securing their right to existence. By implication, here, the other is the human component that has no (economic) utility. In the text, this other appears in the form of the elderly ("Grandma") and the young (the imprisoned children). The children are not represented true to life, but personified by masked actors from time to time. The further on in the performance, the clearer the theatrical representation becomes, until it finally culminates in their death.

The displaced position of the spectators during the transmission of bodily pain

In the first half of the performance, the spectators are seated on hard, narrow chairs at long dining tables. As the individual scenes take place around them, they glance sideways and turn their heads to see the scenes and toward the lectern. The uncomfortable sitting position and the resulting neck pain are reminders of the uncertainty of one's own health, and are precursors to the second half of the performance. It is not yet clear that the first half will take place on the stage and that the audience is already sitting where the euthanasia victims are going to die in the third scene. In the breaks between the two parts, the audience is taken through the exhibition "The War against the 'Inferior': On the History of Nazi Medicine in Vienna" and around the outside of the building. They walk along the steles, which appear as small, bright silhouettes, set apart from the darkness of the surroundings. They are led past a shady grove in the Vienna Woods, which has come to be associated with infanticide, due to Ödön von Horvath's Tales from the Vienna Woods.

In the second part, the audience is back inside the auditorium of the Jugendstiltheater. Switching their position from the tables to the raised seating of the auditorium re-theaterizes the world of the proscenium theater. It symbolizes a passage to the historical past, to past theatrical conventions and to the immediate past - to that same evening before the intermission. The red curtain lifts and the audience is seated behind the mirror (Spiegel) of the Spiegelgrund areal. The spectators now view the space they sat in at the beginning. They look out over the site of the (Nazi) past, the site of their previous participation. The reflection of the spatial structure corresponds to the reflection of the past and the future, in which the place of the present and the self (in Marthaler's piece) are irreconcilable. The precarious present constantly slips into what was and what will be. The spatial 
set-up and the spectator's own placement in the space is disrupted through the change of perspective. It is impossible for the spectators to withdraw their perception and retreat to a secure place, for them to trust themselves, and for them to unambiguously and permanently assume a position of (identification with) the victim(s) or the perpetrator(s). One of the performers speaks about the experiences of a torture victim who, as a small boy, was tied up in a wet sheet at the euthanasia clinic for hours, until the sheet was dry and his body had become stiff. The stiffness of the spectators' necks is a bodily transferred trace of the stiffening of the torture victim's body. Of course, the multilayered pain of torture can never fully be represented or made present on stage. In Schutz vor der Zukunft, the trace of of bodily discomfort elicits a response to the violation of the precarious existence that is staged in the performance. The mimetic stiffness is retained in the spectator's body as a minimal trace of the suffering of the other. This stiffness in the spectators' bodies is a reminder of the tales of torture. However, and this is of crucial importance, it also bears witness to the non-representability of the traumatic (Holocaust) and from the impossibility to comprehend the afflicted pain. The spectators' displaced / angled position can be read as a reference to the impossibility to comprehend the suffering. At the same time, "stiffness" is a recurrent theme throughout the performance. It is in the spectators' bodies, in the text, and in the illuminated stellae, each one dedicated to a child who was murdered. The homepage of the Wiener Krankenanstaltsverbundes (Vienna hospital network), which currently manages the space, describes the stellae as follows: "the 'stiff' arrangement of these posts symbolizes the conditions under which the "Spiegelgrund children" suffered, and the approximately $70 \mathrm{~cm}$ distance between them clearly demonstrates their total deprivation of freedom" (www.wienkav.at/kav/ows).

The spectators become witnesses of the unrepresentability of horror: although the stiff neck sinks into the body memory, it can never fully resonate the pain of the torture victims. Nonetheless, the tales of torture following the intermission link the bodily discomfort (that arises before the intermission) with a concrete story. The spectator's body like a faint echo, follows the trace of the other who, nonetheless, will have irrevocably and irretrievably preceded the spectator. Kati Röttger points out that forgetting forms an active part in the process of remembering within theatre performances. Similarly, with Marthalers performance it becomes evident that it is not possible to fully remember, or re-stage, the horror of the Nazi regime. 


\section{b) The dramaturgical rhythm of the liminal}

Historically and currently, the former Spiegelgrund areal is a liminal space. Today, it is part of what is known as Baumgartner Höhe, which links the city of Vienna with the surrounding Vienna Woods. Surrounding it is a popular recreational area, which is also connected to the infanticide motif owing to Ödon von Horvath's theater text Tales from the Vienna Woods. It represents the passage from justice to injustice, healing to murder, and today, from sickness to health.

The second half of the performance is also liminal, as it moves towards the children's murder. It is a passage from their lives to their death, and is organized though the progressively increasing rhythm of the alternation from motionlessness song scenes to spoken scenes with motion. In the beginning, these two types of scenes alternate, then towards the end, the spoken scenes diminish as the song scenes become more frequent. Spoken language is silenced, song and movement intersect, and the motionless scenes become increasingly speechless. The rhythm of these chiastic intersections noticeably picks up its pace. The song, a sliding "between sensuality and sense / meaning" (Risi 273), places the last part of the performance in connection with the narrative of death. It smuggles the "children" from the world of the living into the world of the dead. These rhythms touch the audience's ears as sound waves, which effortlessly bridge the distance that visual impressions are less apt to overcome.

Voices have the capacity to connect text and body, or more specifically, sense / meaning and sensuality, because they emerge from the body and reach the body - the listeners ears - as sound waves. While sight functions by viewing things from a distance, the sound waves produced by voices carry beyond the boundaries of the stage, as they move toward the spectators. As the sound waves reach their ears and touch them, a corporeal sound space emerges. Hans-Thies Lehmann emphasizes that in theater "the invitation to listen" seemingly creates "bodily contact” and that saying "'Listen to me' means: Touch me, acknowledge that I exist." (35). In this way, a claim is made to the vulnerable other, which Lehmann - similar to Butler - finds quite strikingly formulated in the acoustic realm. The sound waves carry the trace of the other, which could be read as an acknowledgement of its existence or its history. The torture victim's narrative in the second half of the performance touches the spectators' bodies, which are already affected by a potentially uncomfortable feeling, due to their stiff necks. It provides a narrative space for corporeal perception.

In the second part, the music and song gain the upper hand, until the clearly organized speech becomes silent. The voices express themselves in a language that grows less and less comprehensible, squeaking and quacking like animals over the din of the brass instruments, losing their humanity. The sound of creepy 
"laughter" evokes clichés of mental hospitals. The movements become more and more choppy and - aside from the monologue passage - lack any sense of naturalness: with isolated movements of individual parts of their bodies, the actors mostly move toward the spectators facing them. There is a head stuck inside a trombone; legs jerk about on their own, voices break into stuttering, and faces disappear behind masks - creating a mélange of beauty, humor and horror. Individual sounds that are made with the body - like clapping hands or loud steps - and ring out into the silence.

In the final scene, the actors are huddled close together. Their masks look like stylized children's faces. Their feet begin to slip out from under them, their legs quiver and thrash about, they run into and away from each other until they fall to the floor. Just as the language structure disintegrates more and more as the performance progresses, the structure of the body movements falls apart as well. Here, falling, which Marthaler has employed in numerous other productions, is employed to decelerate the movement. Within the context of murder, it also carries the connotation of the definitiveness of death. The death wish (desire), present in Marthaler's staging of Der Eindringling and Pelléas und Mélisande (Lilienthal 124), returns here, in the form of murder. The desire motif, however, is present in some of the romantic lyrics, which have a soothing effect.

The beauty of the music is contrasted with the spectators' awareness of the horrific murders that took place at Spiegelgrund. The music produces a utopian moment and makes time stand still. The sound space that emanates from the stage area and into the auditorium melds with the horrific events. The Wiener Festwochen, as a place of bourgeois high culture, are re-inscribed with a different meaning: Schutz vor der Zukunft is a tale of Austria's theatrical selfrepresentation as a theater nation, built upon the graves of the dead (children).

Marthaler's performance is posttraumatic because it performs the double nature of trauma between unrepresentability and over-representation (see Caruth above) in the face of the history of Nazi euthanasia. The spectators' corporeality is addressed, as in Meg Stuart's Blessed, whereby in Stuart's case the discomfort remains unspecified, because the performance is not embedded in a specific historical context. The theater works discussed here stages the precarious by engaging the spectators' senses, far beyond the gaze. By not using actors to represent the other, the theater-makers discussed here produce less visual representations of its precariousness (in contrast to the mass media), and very often they employ a specific acoustics, smell, and a certain bodily unease that cannot finally be pinned down, or explained. The absence of the other (on stage) is evidence of previous suffering, the existence of a trauma that is made present through incessant rainfall, through song, through recordings of songs and radio 
interviews, and through painful seating arrangements within theater spaces. Therefore, the spectators' corporeal perception can be read not only as traces of the other but, more precisely, as traces of its disappearance. Its character of the trace carries in it the double nature of the traumatic, of being simultaneously absent and present.

\section{Works Cited}

Agamben, Giorgio. Homo Sacer: Die souveräne Macht und das nackte Leben. Frankfurt a.M.: Suhrkamp, 2002.

Arias, Lola. Mein Leben danach. Frankfurt a. M.: Verlag der Autoren, 2010.

Barnett, David. "Christoph Marthaler: The Musicality, Theatricality and Politics of Postdramatic Direction." Contemporary European Directors. Ed. Maria M. Delgado, and Dan Rebellato. New York: Routledge, 2010.185-205.

Bechara, Suha. Zehn Jahre meines Lebens für die Freiheit meines Landes. München: Hugendubel Verlag, 2001. Zit. in: Hillauer, Rebacca: “'Ich fühlte so etwas wie Stolz' - Aus dem Leben einer libanesischen Widerstandskämpferin.” In: Wajdi Mouawad: Verbrennungen. Programmheft zur Aufführung. Burgtheater Wien 2007. 19-22.

Butler, Judith. Precarious Life. The Powers of Mourning and Violence. London, New York: Verso, 2004.

Butler, Judith. "Politics Under Conditions of Precariousness and Violence. A Conversation between Judith Butler and Antke Engel." New Feminism. Worlds of Feminism, Queer and Networking Conditions. Ed. Griznic, Marina and Rosa Reitsamer. Vienna: Löcker, 2008. 135-147.

Carlson, Marvin. Theatre is More Beautiful Than War. German Stage Directing in the Late Twentieth Century. lowa City: U of lowa P, 2009.

Caruth, Cathy, ed. Trauma. Explorations in Memory. Baltimore, London: John Hopkins UP, 1995. Freud, Siegmund. “Über den psychischen Mechanismus hysterischer Phänomene. Vorläufige Mitteilung." Gesammelte Werke. Vol. 1 Frankfurt a. M.: Fischer, 1999. 76-98

Janke, Pia, ed. Die endlose Unschuldigkeit. Elfriede Jelineks 'Rechnitz (Der Würgeengel)'. Vienna: Praeses Verlag, 2010.

Kolesch, Doris and Jenny Schrödl, eds. Kunst-Stimmen. Theater der Zeit Recherchen. Vol. 21. Berlin: Theater der Zeit Recherchen, 2004.

Lehmann, Hans-Thies. "Prädramatische und postdramatische Theaterstimmen. Zur Erfahrung der Stimme in der Live-Performance." Kolesch and Schrödl 40-68.

---. Postdramatic Theatre. New York: Routledge, 2006.

---."Ein Schritt fort von der Kunst (des Theaters). Überlegungen zum postdramatischen Theater." Kunst Fortschritt Geschichte. Ed. Christoph Menke and Juliane Rebentisch. Berlin: Kulturverlag Kadmos, 2006.169-178.

---.“Die postdramatische Chance der Autoren.” http://www.heidelberger-stueckemarkt.nachtkritik.de/index.php/debatte, 1.5.2014, 10:32.

Lilienthal, Matthias. Eine untergangene Welt ein letztes Mal imaginieren. In: Dermutz, Klaus. Christoph Marthaler: die einsamen Menschen sind die besonderen Menschen. Salzburg: Residenz Verlag, 2000. 113-125. 
Lévinas, Emmanuel. Ethics and Infinity: Conversations with Philippe Nemo. Pittsburgh: Duquesne UP, 1985.

---. Totalität und Unendlichkeit. Versuch über die Exteriorität. Freiburg, München: Karl Alber Verlag, 1987.

---. Basic Philosophical Writings. Ed. Adriaan T. Peperzak, Simon Critchley, and Robert Bernasconi. Bloomington: U of Indiana P, 1996.

Pewny, Katharina. Das Drama des Prekären. Über die Wiederkehr der Ethik in Theater und Performance. Bielefeld: Transcript, 2011.

---. "Performing the Precarious. Economic Crisis in European and Japanese Theatre (René Pollesch, Toshiki Okada)." Forum Modernes Theater 1 (2012): forthcoming.

Ridout, Nicolas. Theatre \& Ethics. New York: Palgrave Macmillan, 2009.

Risi, Clemens. "Rhythmus." Metzler Lexikon Theatertheorie. Eds. Erika Fischer-Lichte, Doris Kolesch, and Matthias Warstat. Stuttgart, Weimar: Metzler, 2005. 271-274.

Roesner, David. Theater als Musik. Verfahren der Musikalisierung in chorischen Theaterformen bei Christoph Marthaler, Einar Schleef und Robert Wilson. Tübingen: Narr Verlag, 2003.

---. "The politics of the polyphony in performance. Musicalization in contemporary German theatre (Ruedi Hausermann, Sebastian Nubling, Heiner Goebbels, Christoph Marthaler, Einar Schleef)." Contemporary Theatre Review 18.1 (2008): 44-55.

Röttger, Kati. "Macht van de geschiedenis - Geschiedenis van de macht? Gevallen goden en vergeten geesten op toneel." Ornamenten van het Vergeten. Eds. Lucia van Heteren, Chiel Kattenbelt, Christel Stalpaert, and Robert van der Zalm. Amsterdam: Amsterdam UP, 2007. 45-56.

Schneider, Rebecca. Performing Remains: Art and War in Times of Theatrical Reenactment. London: Routledge, 2011.

Siegmund, Gerald. "Unclaimed and Unclaimable. Memories of the RAF." Performing Cultural Trauma in Theatre and Film. Eds. Frederik Le Roy, Christel Stalpaert, Sofie Verdoodt. arcadia 45.2 (2010): 387-405.

Van den Berg, Klaus. “Contemporary German scenography. Surging images and spaces for action (Achim Freyer, Bert Neumann, Anna Viebrock, Olaf Altmann)." Contemporary Theatre Review 18.1 (2008): 6-19. 